\title{
Impact of Discussion Boards to the Success of English Lesson
}

\author{
Harun Yilmaz \\ The Scientific and Technological Research Council of Turkey (TÜBİTAK), Ankara, Turkey \\ Email: harunyilmaz@gmail.com \\ Duygu Sağlam \\ Zonguldak Karaelmas University, Zonguldak, Turkey \\ Email: duygusefercik@hotmail.com
}

\begin{abstract}
Computer technology has developed and become an indispensable mean to reach the information and communicate with peers in an organized way. Discussions are the keys to enhance the communication among learners. Online peer response that blends written and electronic communication can promote student participation and collaboration. Hence, utilizing online discussion in language learning has potential to increase practice and improve student learning. This study investigated the effects of using discussion on students' achievement in online courses using the pre-test post-test with control group experimental research design with 32 students studying in the Undergraduate Compulsory Preparatory Program of a state university. Findings of the study showed that integrating discussion in online courses improves students learning more than online courses that do not include discussion.
\end{abstract}

Index Terms - computer assisted language learning, discussion boards, communication, language learning

\section{INTRODUCTION}

Recent developments in the Internet technology offered various ways to realize many second language learning theories. One of these learning theories is Michael Long's interaction hypothesis suggesting "language is acquired as learners actively engage in attempting to communicate in the target language" (Nunan, 1999, p.51). However, as we all experience even in our native languages, communication is not always so smooth. There are times when we do not understand what the other party has said. When it happens, they signal their interlocutors that they did not understand what they have just said. In that case, their interlocutor tries to find alternative ways, such as paraphrasing or using other cues, to make their language more comprehensible. It the process of the negotiation of meaning where interlocutors experience difficulty in understanding what has been said -possibly as a result of a lack of some linguistic or lexical knowledge of either side- and seek for ways to understand each other. This process is called the negotiation of meaning, and according to Long, it is very crucial for language acquisition (Long, 1985). This type of interactional modifications is believed to be promoting L2 acquisition, even though there is little empirical evidence supporting such arguments (Ellis, 1994, 1997; Nunan, 1999).

Blake's (2000) study emphasizes the Interaction Hypothesis as a base point of using a particular technology tool in a foreign language classroom. His study examined 50 intermediate Spanish learners' networked discussions through Remote Technical Assistance (RTA) by which users can exchange digitized sound, manipulate each other's web browser, and do point-to-point or group chat. As a result, Blake (2000) stated that "Well-designed networked tasks promote learners to notice the gaps in their lexical intedanguage in a manner similar to what has been reported in the literature for oral learner/leamer discussions" (p.132). In other words, when the learners were completing the tasks, they occasionally failed in communicating with each other. At these moments, they noticed what is problematic in their interlanguage, e.g. lack of lexical items or morphological confusions, then they try to gather the meaning by asking questions, which is called the negotiation of meaning.

Another important finding of the study is that this kind of networked interaction allows all participants equal and increased participation. Such increased opportunities for learners to get involved in social interactions with their peers could also be interpreted as a real life application of Vygotsky's (1978) social development theory proposing that learning takes place on social level before it becomes a mental process for an individual. Although the learners did not actually talk the target language in an online community, the author concluded that "CMC (computer-mediated communication) produces similar benefits to those of oral discussions without the temporal and spatial constraints imposed by the classroom" (Blake, 2000, p.132). As many other studies claimed (Chun, 1994; Kern, 1995) that such online communication tools create a friendlier atmosphere where learners feel no peer or teacher pressure when they are communicating online, which results in higher motivation to talk (Donaldson \& Morgan, 1994).

\section{LITERATURE REVIEW}




\section{A. Zone of Proximal Development}

Related to the interactional hypothesis of Long, Vygotsky's zone of proximal development (ZPD) (Vygotsky, 1978) and social development theory are of great importance regarding second language acquisition. Vygotsky argued that higher mental functions such as voluntary attention and problem-solving are related to social interaction of child, which is mainly mediated by speech. Child's social interaction, through speech or other means such as play or online activities, plays a crucial role in child's development. In sociocultural approaches, students' participation is the main purpose of language learning and a key factor of acquisition process (Kasper, 2001; Lantolf \& Thorne, 2006; Pavlenko \& Lantolf, 2000).

In the process of ZPD, another important term that needs clarification is scaffolding. Scaffolding is a technique used by teachers to move children through their ZPD by supporting and also challenging them to be active learners. Scaffolding, which can also be described as "assisted performance" (Tharp and Gallimore, 1991), is one of the requirements of the successful ZPD (Ohta, 2000). According to Ohta, "development cannot occur if too much assistance is provided or if a task is too easy" (2000, p.52). This statement, indeed, describes what scaffolding is providing assistance just as needed and providing challenging tasks.

Kern's (1995) prominent study supported the benefits of CMC in classroom discussions. In his study, Kern analyzed the students' interaction using the InterChange software, a chat program, and compared them with their oral production during an oral discussion of the same topic. He also investigated students' and teachers' perception of using the InterChange software.

The results of the study showed that there were "striking differences in quantity production between InterChange and oral discussions" (Kern, 1995, p.464). To give an idea, the InterChange students took an average of 11.8 turns, whereas the oral discussion students took an average of 5.4 turns. Just this number alone shows that the participants of this study were more actively involved in the communication process through the InterChange than regular oral discussions. Chun (1994), who found similar results in her study, explained the reason for more active participation as following:

"A decided advantage of CACD is that learners are under neither time pressure to respond, nor the physical pressure of making a mistake or looking foolish. In addition, the length and breadth of their entries are not restricted, and their individual styles are allowed to flourish" (p.28).

Clearly, students feel more comfortable when they are talking by writing as opposed to talking by talking. Especially having the chance to think about what they are going to write gives them stronger self-confidence when they are initiating any conversation or participating to an ongoing interaction (Braine, 2001; Ware, 2004).

Sotillo (2000) studied in synchronous and asynchronous communication to explore the discourse functions and syntactic complexity. The researcher found that both synchronous and asynchronous groups, despite the teachers' attempts to control the focus of the discussions, managed to change the topic. Although it seems to be a negative aspect, especially in terms of the teachers' classroom management, the author maintained that this is the strength for this group of students because they realized purposeful action in collaboration. Furthermore, Sotillo (2000) argued that the students' collaborative efforts to create the text and context would, in Vygotsky's terms, serve as a mediational tool to generate new meanings collaboratively.

Sotillo (2000) also maintained that, since the asynchronous group did have more time to think about their responses and compose them coherently, they were able to focus on both form and meaning more synchronous group where the participants needed to faster and constantly. Therefore, it would be reasonable to claim that learners pay more attention to form and meaning when they are communicating through a synchronous communication too than students engaging in regular oral classroom discussions which require them to talk very fast and as smoothly as possible (Yuan, 2003). In parallel of these results, several studies produced the findings demonstrating that text-based online communication such as discussion boards is helpful for oral communication (Blake, 2009; Satar \& Özdener, 2008).

\section{B. Student-centeredness and Student Autonomisation}

Student centeredness and student autonomisation are also among the trendy issues in foreign language education. Enhancing student autonomy and control over the language learning process is one of the main goals of modem language teaching approaches (Warschauer, Turbee, \& Roberts, 1996). Learner autonomy is sometimes considered as self-instruction, but definitely it is not all of it.

In this process of making students more autonomous, the teachers' role is very important. In order to create an environment where scaffolding to occur, teachers are supposed to guide students gradually to be autonomous learners. For example, Donaldson and Kotter's (1999) study involving one of the synchronous CMC tools created such an environment in which students took control over what they wanted to do with the target language they were practicing.

As a result of the study, Donaldson and Kotter (1999) asserted that "unmistakable success of the independent learning that took place in the project indicates that the MOO is a powerful tool in the arsenal of technological weapons to aid learning" (p.543). It was one of the goals of the study to show that the online environment is a relatively good tool for autonomous learning, where teacher help is available just when it is needed. The authors also stated that the playful nature of the MOOs maintained very high motivation amongst the learners to participate in the online activities which resulted in better language learning.

\section{Authentic Data and Use of Discussion Boards}


Using authentic data in foreign language teaching is quite essential. Nunan (1999) describes authentic data as "samples of spoken and written language that have not been specifically written for the purposes of teaching language" (p.27). By this definition, any attempt to modify any authentic would "de-authenticate" it. Teaching with contrived pieces of language samples may not help learners to gain the language that they can use in real life situations. However, it is not possible to supply the learners all the time with $100 \%$ authentic data. Nunan (1999) states that "learner should be fed as rich a diet of authentic data as possible, because, ultimately, if they only encounter contrived dialogues and listening texts, their task will be made more difficult" (p.27). All in all, if the purpose of foreign language teaching is to prepare learners for real-life communication in the respective foreign language, it is essential to get them familiar with as much authentic data as possible.

New technologies, such as various Internet tools, made it easier for teachers to incorporate authentic data in their teaching. One of the best examples of these internet tools is discussion boards that provide an environment for the users to discuss a topic and interact each other. The discussion board is defined by Rovai (2001) as an online classroom. In order to create a community of practice and reach a success in this online class, there should be a small group that participates in the discussions and the instructor playing a facilitator role in this environment (Kling \& Courtright, 2003).

Learner participation is one of the key factors affecting online learning. In the literature, there are several studies focusing specifically on learner participation. While Woods (2002) asserted that interaction between the instructors and peers is vital to be successful in online environments, Davies and Graff (2005) found a relationship between participation level and students' grades.

Because of the enthusiastic approaches of many researchers to the use of new technologies in language classrooms, some studies do not even mention any problems encountered during the application of such technologies. It would be naive to suggest that those studies implemented perfectly without any problems.

Olivia \& Pollastrini (1995) reported that some learners complained about the overwhelming technical skills they needed to learn in order to participate in the study. Naturally, not all students were technologically able. Kern's (1995) also highlighted some drawbacks of using CMC tools as a part of teaching/learning process. In her study, teachers felt that their control over classroom was compromised. The results of the questionnaire showed that the teachers were not as enthusiastic as the students towards the use of technology. These two results confirm each other. In other word, as a result of the teachers' loss of control over the class interaction, they also lost their enthusiasm towards the tool that caused it. This result shows that teachers should be trained more about the importance of student-centered classroom along with methods to negotiate the freedom given to students in order to avoid chaotic classrooms because of authority.

\section{RESEARCH QUESTIONS}

The following three major research questions regarding the usage of discussion boards were targeted in our research:

Is there a difference between the structure level of the students using discussion board in online instruction before and after the study?

Is there a difference between the structure level of the students who did not use the discussion board in online instruction before and after the study?

Is there a difference between the gain scores of the students using the discussion board in online instruction and the gain scores of the students not used the discussion board in online instruction?

\section{METHOD}

\section{A. Instructional Context}

This study was applied to an Undergraduate Compulsory Preparatory Program of a state university in Turkey. Integrated skills are mainly used throughout the courses and laboratories to enhance the students' second language acquisition. In the program, technological devices like computers, overhead projectors, reflecting projectors, DVD and CD players are highly used. The courses are supported by an interactive computer program including many kinds of exercises for target language. At the end of the term, students are expected to acquire the language.

\section{B. Participants}

The 32 participants were chosen randomly from two equal level classes in Undergraduate Preparatory Program of a state university. Of the 32 students, 16 were female and 16 were male. They are named as experimental group including 18 students and control group including 14 students. The difference of these groups is the experimental group has a discussion board which students can indicate their own opinions and comment on their friends' opinions.

\section{Research Design}

This study investigated the effects of using discussion boards on students' achievement in online courses using the pre-test post-test with control group experimental research design. The students are informed about the implementation before the process. A grammar rule was chosen for the target groups and taught for four weeks in exe-learning program which was presented in Moodle. Both groups were responsible for the personal information, grammar review and 
practice parts. In addition to these, experimental group was expected to indicate their own opinions and comments on their friends' ideas as peer-correction in the discussion board of the program. During the program, control group only made self-study. Before and after the study, a multiple choice test was applied to both groups.

\section{RESULTS}

The first research question investigated whether there was a difference between the structure level of the students using discussion board in online instruction before and after the study. The result of the Wilcoxon Signed Rank Test for Paired Samples was presented at the Table 1. Results indicate that the structure level of the students using discussion board in online instruction after the study is significantly higher than the structure level of the students using discussion board in online instruction before the study.

TABLE 1.

THE RESULTS PRE-TEST POST-TEST COMPARISON OF THE EXPERIMENTAL GROUP USING THE WILCOXON SIGNED RANK TEST FOR PAIRED SAMPLES

\begin{tabular}{cccccc}
\hline & $\mathrm{n}$ & Mean Rank & Sum of Ranks & $\mathrm{Z}$ & $\mathrm{p}$ \\
\hline Post-Pre Test & 0 & 0 & 0 & $3.724^{*}$ \\
Pegative Ranks & 18 & 9.5 & 171 & \\
Positive Ranks & 0 & & \\
Ties & *Based on negative ranks
\end{tabular}

The second research question investigated whether there was a difference between the structure level of the students who did not use the discussion board in online instruction before and after the study. The result of the Wilcoxon Signed Rank Test for Paired Samples was presented at the Table 2. Results indicate that the structure level of the students who did not use the discussion board in online instruction after the study is not significantly different from the structure level of the students who did not use the discussion board in online instruction before the study.

TABLE 2.

THE RESULTS PRE-TEST POST-TEST COMPARISON OF THE CONTROL GROUP USING THE WILCOXON SIGNED RANK TEST FOR

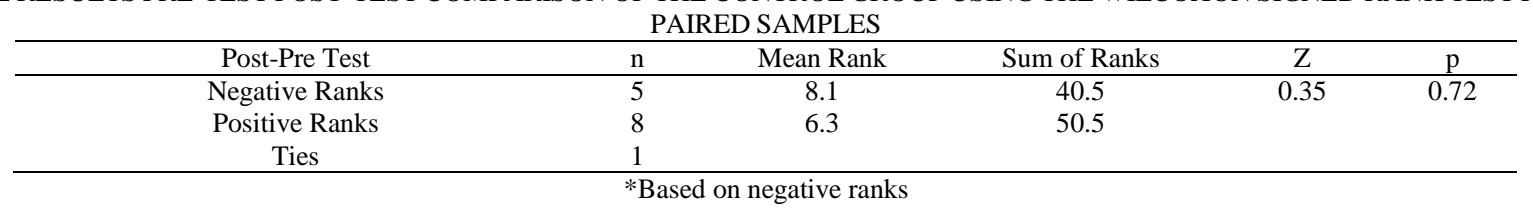

The third research question investigated whether there was a difference between the gain scores of the students using the discussion board in online instruction and the gain scores of the students not used the discussion board in online instruction. The result of the Mann Whitney U-test for Independent Samples was presented at the Table 3. Results indicate that the gain scores of the students using the discussion board in online instruction are higher than the gain scores of the students not used the discussion board in online instruction.

TABLE 3.

THE COMPARISON OF THE GAIN SCORES FOR THE EXPERIMENT AND THE CONTROL GROUP USING THE MANN WHITNEY U-TEST FOR INDEPENDENT SAMPLES

\begin{tabular}{cccccc}
\hline Groups & $\mathrm{n}$ & Mean Rank & Sum of Ranks & $\mathrm{U}$ & $\mathrm{p}$ \\
\hline Experimental & 18 & 9.07 & 127 & 22 & 0
\end{tabular}

The results of this study demonstrated that there is no significant difference between the structure level of the students who did not use the discussion board in online instruction before and after the study. It seems that students keep their learning pace without using discussion boards. On the other hand, the results indicated that students who used discussion boards produced higher scores than students who did not use discussion boards. This suggests that student may perceive the inputs which interactionally and collaboratively are modified by peers, are given in text form in discussion boards (Warschauer, 1996).

Students who have participated in discussion board activities seemed to pay attention to a morphosyntactic operation, specifically in the context of Simple Past Tense in this study. It seems that interactions in discussion boards enable students to consider additional resources on the web to give responses to peers and use different strategies to communicate with them (Ortega, 1997). The results confirmed that students feel more comfortable when they are talking by writing to communicate or participate in an interaction in online environment (Ware, 2004). One of the reasons of having more comfortable may be that students have more time to think about what they need to response or 
give feedback (Yuan, 2003). In addition, use of discussion boards in language learning makes students more autonomous and maintains high motivation amongst the students to participate in discussion boards which produced better language learning (Donaldson, \& Kotter, 1999).

The study revealed that use of discussion boards has a positive effect on ESL students' learning. As a successful case of English language learning, we believe that the more interaction occurs in online environment between students to students and students to an instructor in the case of language learning, the more student learning and use of different teaching strategies are encouraged.

Future studies can focus on the analysis of discussions, as well as quantitative results with larger samples. In addition, conducting interview with students can help researchers to support the results.

\section{REFERENCES}

[1] Blake, R. (2000). Computer mediated communication: A window on L2 Spanish interlanguage, Language Learning Technology, 120-136. Retrieved from the World Wide Web: http://lt.msu.edu/vol4num1/blake/default.html

[2] Blake, C. (2009). Potential of text-based internet chats for improving oral fluency in a second language. The Modern Language Journal, 93(2), 227-240.

[3] Braine, G. (2001). A study of English as a foreign language (EFL) writers on a local-area network (LAN) and in traditional classes. Computers and Composition, 18(3), 275-292.

[4] Chun, D. M. (1998). Using computer-assisted class discussion to facilitate the acquisition of interactive competence. In J. Swaffar, S. Romano, K. Arens, and P. Markley (Eds.), Language learning online: Theory and practice in the ESL and L2 computer classroom (pp. 57-80). Austin, TX: Labyrinth Publications.

[5] Davies, J. \& Graff, M. (2005). Performance in e-learning: online participation and student grades. British Journal of Educational Technology, 36(4), 657-664.

[6] Donaldson, R.P., \& Morgan, L.Z. (1994). Making the most of scarce resources: A small college language department's experiences with HyperCard, CALICO Journal, 11(4), 41- 60.

[7] Donaldson, R. P. \& Kotter, M. (1999). Language learning in cyberspace: Teleporting the classroom into the target language culture. CALICO Journal, 16 (4), 531-557.

[8] Ellis, R. (1994). The study of second language acquisition. Oxford: Oxford University Press.

[9] Kasper, G. (2001). Four perspectives on L2 pragmatic development. Applied Linguistics, 22(4), 502-530.

[10] Kern, R. G. (1995). Restructuring classroom interaction with networked computers: Effects on quantity and characteristics of language production. The Modern Language Journal, 79(4), 457-476.

[11] Kling, R., \& Courtright, C. (2003). Group behavior and learning in electronic forums: A sociotechnical approach. The Information Society, 19(3), 221-235.

[12] Lantolf, J.P., \& Thorne, S.L. (2006). Sociocultural theory and the Genesis of L2 development. Oxford: Oxford University Press

[13] Long, M.H. (1985). A role for instruction in second language acquisition. In K. Hyltenstam \& M. Pienemann (Eds.), Modeling and assessing second language acquisition. (pp.77-99). Clevedon, Avon: Multilingual Matters.

[14] Nunan, D. (1999). Second language teaching and learning. Boston: Heinle \& Heinle.

[15] Ohta, A. (2000). Rethinking interaction in SLA: Developmentally appropriate assistance in t he zone of proximal development and the acquisition and L2 grammar. In J. Lantolf (Ed.), Sociocultural theory and second language learning (pp. 51-78). Oxford, UK: Oxford University Press.

[16] Olivia, M., \& Pollastrini, Y. (1995). Internet resources and second language acquisition: An evaluation of virtual immersion. Foreign Language Annals, 28(4), 551-563.

[17] Ortega, L. (1997). Processes and outcomes in networked classroom interaction: Defining the research agenda for L2 Computerassisted Classroom Discussion. Language Learning \& Technology, 1(1), 82-93.

[18] Pavlenko, A., \& Lantolf, J.P. (2000). Second language learning as participation and the (re)construction of selves. In J. P. Lantolf (Ed.), Sociocultural theory and second language learning (pp. 155-177). Oxford: Oxford University Press.

[19] Rovai, A. P. (2001). Building classroom community at a distance: A case study. Education Technology Research and Development, 49(4), 33-48.

[20] Satar, H. M., \& Özdener, N. (2008). The effects of synchronous CMC on speaking proficiency and anxiety: Text versus voice chat. The Modern Language Journal, 92(4), 595-613.

[21] Sotillo, S. M. (2000). Discourse functions and syntactic complexity in synchronous and asynchronous communication. Language Learning and Technology, 4 (1), 82.

[22] Tharp, R., \& Gallimore, R. (1991). The instructional conversation: Teaching and learning in social activity (Research Report 2). Santa Cruz, CA: The National Center for Research on Cultural Diversity and Second Language Learning, University of California, Santa Cruz.

[23] Vygotsky, L.S. (1978). Mind in society: The development of higher psychological processes. Cambridge, MA: Harvard University Press.

[24] Ware, P. (2004). Confidence and competition online: ESL student perspectives on web-based discussions in the classroom. Computers and Composition, 21, 451-468.

[25] Warschauer, M. (1996). Comparing face-to-face and electronic discussion in the second language classroom. CALICO Journal, 13(2), 7-26.

[26] Warschauer, M., Turbee, L, \& Roberts, B. (1996). Computer learning networks and student empowerment. System, 24 (1), 1 14.

[27] Woods, R.H.J. (2002). How much communication is enough in online courses? Exploring the relationship between frequency of instructor-initiated personal email and learners' perceptions of and participation in online learning. International Journal of Instructional Media, 29 (4), 377-394. 
[28] Yuan, Y. (2003). The use of chat rooms in an ESL setting. Computers and Composition, 20(2), 194-206.

Harun Yılmaz received his Ph.D. degree in Instructional Design and Technology from Virginia Tech (2007), USA. He worked as an instructional designer and instructor at University of Phoenix from 2005 to 2007. He is currently working at the Scientific and Technological Research Council of Turkey (TÜBİTAK), Turkey as a scientific programs expert.

Duygu Sağlam received his B.S. (2005) degree in English Language Teaching from Kocaeli University, Turkey. She is seeking M.Sc. degree in Curriculum Development and Instruction and working as an instructor at the Foreign Languages Compulsory Preparatory Program, Zonguldak Karaelmas University, Zonguldak, Turkey. 